\title{
Donepezil Improves Histological and Biochemical Changes in the Hippocampus of Adult Hypothyroid Male Rats
}

\section{Original Article}

\author{
Dalia A Mohamed and Samah M Ahmed
}

Department of Histology and Cell Biology, Zagazig University, Zagazig, Egypt

\begin{abstract}
Introduction: Hormonal imbalances are involved in many related pathologies, such as neurodegenerative and psychiatric disorders. Adult hypothyroidism is a prevalent condition in humans with an incidence of $8 \%$ in the adult population and could impair learning and memory processes. Even though tetra-iodothyronine (T4) treatment can overcome the hypothyroidism in the majority of cases, it cannot fully recover the patient's learning capacity and memory. Donepezil (DON) was a cholinesterase inhibitor, that can effectively improve the cognitive and memory impairments.

Aim of work: This work analyzed the histological and biochemical changes in the hippocampal Cornu Ammonis (CA1) region occurring in experimental hypothyroidism and assessed the possible role of Donepezil in such condition.

Materials and Methods: Forty eight healthy adult male rats were randomly divided into four groups; Group I (control group), rats of group II were subjected to thyroidectomy, Group III (thyroid-supplemented) and Group IV (combined $\mathrm{DON}+$ thyroxin). The hippocampus (CA1 region) sections were prepared and stained with hematoxylin and eosin and Cresyl fast violet. Immunohistochemical staining for glial fibrillary acid protein (GFAP), P53 and calretinin and electron microscopic examination were also done. The results were statistically analyzed.

Results: Hippocampus of hypothyroid adult rats displayed increased apoptosis in neurons and astrocytes with reactive gliosis as compared with controls. Moreover, the oxidative stress markers increased. Thyroid replacement induced some improvement, however DON could improve some of alterations to be similar to normal.

Conclusion: Our data concluded that adult hypothyroidism affects the hippocampus by a mechanism that alters the composition of GFAP, reduced neuronal and astrocyte survival, and alters the content of oxidative redox. Thyroxin replacement improved the structural alterations within limits. However combined thyroxin with DON could improve almost all of the biochemical and histological alterations.
\end{abstract}

Received: 11 May 2018, Accepted: 24 July 2018

Key Words: Donepezil; hippocampus; histology; hypothyroid; rat.

Corresponding Author: Dalia A Mohamed, Histology and Cell Biology Department, Faculty of Medicine, Zagazig University, Egypt, Tel.: +20 1223168887, E-mail: daliafarag@gmail.com

ISSN: 1110-0559, Vol. 41, No. 4

\section{INTRODUCTION}

Thyroid hormones (THs) play a crucial role in the development and physiological functioning of different body organs especially the brain. They are essential for its appropriate development and function ${ }^{[1]}$. In the last fifteen years, several studies have indicated that THs have important physiological functions, not only during brain maturation but also in the adult vertebrate brain ${ }^{[2]}$ Concerning the normal neurological development, the THs act as the "time clock" to end the neuronal proliferation and stimulate differentiation. Also, they stimulate the formation and development of neuronal processes, axons and dendrites, as well as synapses formation and development ${ }^{[3]}$.

In the brain, THs deficiency in adulthood has been clearly linked to cognitive dysfunction and depressed $\operatorname{mood}^{[4]}$. Many reports documented that adult-onset hypothyroidism is associated with impairment in learning, verbal facility and spatial tasks ${ }^{[5]}$. Also, compromised thyroid status in the adult may result in morphological changes in hippocampus that strongly implicated in learning, memory and mood ${ }^{[6]}$.

The hippocampus is a brain region that has been implicated in many functions such as mediating negative feedback of the hypothalamus pituitary axis (HPA), regulating behavioral measures of anxiety and spatial navigation learning. Because all of these processes, abnormal hippocampal development may underlie some abnormality in the cognitive performance later in life $\mathrm{e}^{[7]}$.

It was documented that hippocampus exhibits well morphological plasticity in adulthood. It is considered as one of the few brain regions that retain the ability to make new neurons throughout adult life in several mammalian species including humans ${ }^{[8]}$. The generation of new neurons 
in the adult hippocampus is reduced in depressed animal models and enhanced neurogenesis has been implicated in the behavioural effects of antidepressants ${ }^{[9]}$.

Thyroid hormones have a strictly regulated action in the brain as they regulate the neuronal cytoarchitecture, neuronal growth, synaptogenesis and they have widely distributed receptors in the $\mathrm{CNS}^{[10]}$. Also, the oligodendrocyte is a well-recognized target of thyroid hormones in the developing brain and these hormones regulate its production of myelin. The structural integrity of the hippocampus is dependent upon adequate supplies of THs during development and in adult life. Several reports documented that CA1 neurons are known to be particularly vulnerable to aggressive agents. So, early thyroid hormone deficiency leads to impaired maturation of radial glial cells in the CA1 region of the hippocampus ${ }^{[11]}$.

Donepezil is a central acting second-generation cholinesterase inhibitor that was primarily administered for the treatment of mild to moderate cognitive impairment and Alzheimer's disease (AD) ${ }^{[12]}$. It acts through combining with the cholinesterase thus, prevents the hydrolysis of acetylcholine in the brain. It was confirmed that it has an independent neuroprotective effect, including protection of cortical neurons against different toxicities and oxygenglucose deprivation. Also, it could protect against the effects of hippocampal mitochondrial dysfunction. Currently, acetylcholinesterase inhibitors are used in the clinic to treat Alzheimer's disease and many different brain diseases $^{[13]}$.

Gamma-aminobutyric acid (GABA) interneurons are known to play important roles in the regulation of behaviour dependent network activity patterns in the hippocampus. The calcium level within the cells is critical in maintaining the balance of cellular homeostasis and other processes. Calcium binding proteins are thought to play an important role in buffering the calcium level within the cells ${ }^{[14-15]}$. Various calcium-binding protein markers have been found in specific neuronal populations in the nervous system. Among many of these proteins, calretinin (CR) has been established abundantly in several types of neurons. This protein presents in many brain regions, especially hippocampus. In the rodent hippocampus the majority of the CR-positive cells seem to be GABAergic interneurons ${ }^{[16]}$. Spine-free calretinin-immunoreactive (CR-IR) interneurons form a subpopulation of GABAergic cells in the rat hippocampus and are located in all areas and layers $^{[17]}$.

This study was designed to analyze the cellular and molecular effects of induced hypothyroidism on the hippocampus . Also, to investigated the role of DON on the histological and biochemical alterations that caused by hypothyroidism in adult male rats.

\section{MATERIALS AND METHODS}

\section{Animals}

Forty eight adult male albino rats weighing 150-200 g each, were purchased from the Animal House, Faculty of Medicine, Zagazig University, Zagazig, Egypt. The rats were allocated in groups and were allowed to acclimatize to the laboratory conditions for at least 1 week before the start of the experiment. They were housed in a standard animal facility under controlled environmental conditions at room temperature $22 \pm 2{ }^{\circ} \mathrm{C}$ and 12-hour light/dark cycle as well as a constant relative humidity of $50 \pm 5 \%$ throughout the experimental period. The rats were allowed access to standard pellet food and given water ad libitum. The study was approved by the Ethics Committee for Animal Experimentation at Faculty of medicine, Zagazig University, Egypt.

\section{Drugs:}

Thyroid hormone in the form of Levothyroxine sodium was obtained from Glaxo Wellcome Company. Donepezil hydrochloride was purchased from Pfizer (Cairo, Egypt). It was dissolved in saline and administered orally in a dose of $2.5 \mathrm{mg} / \mathrm{kg}^{[18]}$.

\section{Experimental protocol}

\section{Forty eight rats were randomly divided into four groups of twelve rats each:}

Group I (control): subdivided into 3 subgroups; healthy normal control were administrated physiological saline (Ia); sham-operated (Ib) and sham-operated were received Donepezil (Ic).

Group II (operated): were rendered hypothyroid by thyroidectomy.

Group III (thyroid-supplemented): operated rats were treated with thyroxin in the form of Levothyroxine sodium $(10 \mu \mathrm{g} / 100 \mathrm{gm} / \mathrm{BW})$ for successive 3 weeks starting from day one (D1) of operation.

Group IV (combined DON+thyroxin): the operated rats were concomitantly treated with thyroxin and Donepezil $2.5 \mathrm{mg} / \mathrm{kg}$ orally, started from D1 and for successive 3 weeks.

\section{The Operation (Thyroidectomy)}

Hypothyroidism model was induced surgically by thyroidectomy. For this purpose, animals were anesthetized with intraperitoneal injection of $25 \mathrm{mg} / \mathrm{kg}$ sodium thiopental. The thyroid glands were removed through a transverse incision in the upper part of the neck. Skin was carefully reflected from one side of the neck, thyroid gland was recognized from its position close to the trachea and it was also removed. The parathyroids were preserved and received post operative treatment. The sham group (euthyroid animals) underwent the same procedure without thyroid removal ${ }^{[19]}$.

At the end of the experiment, the rats from all groups were fasted overnight. They were sacrificed 6 weeks from the second day after thyroidectomy operation with intraperitoneal injection of $25 \mathrm{mg} / \mathrm{kg}$ sodium thiopental. 
Blood samples were individually collected from each rat in heparinized and nonheparinized glass tubes to estimate some parameters in plasma and serum. Also, the brains were quickly removed and cut coronally with a microtome at 5 um thickness. Sections were fixed in 10\% buffered formalin and embedded in paraffin for histological and immunohistochemical analysis.

\section{Histological study:}

For histological analysis, paraffin-embedded tissue slides were stained with HandE and cresyl fast violet and assessed using a light microscope.

\section{Immunohistochemical study}

Immunohistochemical detection of glial fibrillary acid protein (GFAP), protein 53 (P53) and calretinin protein were carried out using streptavidin-biotin complex immunoperoxidase system. Serial sections of paraffinembedded specimens were deparaffinized and were incubated in $0.1 \%$ hydrogen peroxide for $30 \mathrm{~min}$ to block the endogenous peroxidase and then incubated with the primary antibody for each protein. Thereafter, all sections were incubated with the streptavidin-biotin peroxidase complex and the reactions were visualized with 3', 3 Regular diaminobenzidine tetrahydrochloride (DAB) \{Sigma-Aldrich Chemical Co., St. Louis, USA\} The sections were counterstained with Mayer's hematoxylin, dehydrated and mounted. For negative control sections, the primary antibody was replaced with $\mathrm{PBS}^{[20]}$.

\section{Transmission electron microscope examination}

Specimens for electron microscopy were immediately fixed in $2.5 \%$ phosphate-buffered glutaraldehyde (pH 7.4). Then, they were post-fixed in $1 \%$ osmium tetroxide in the same buffer, dehydrated, and embedded in epoxy resin. Semithin sections were prepared on glass slides through cutting at $1 \mathrm{um}$ using the ultra-microtome. Ultrathin sections were cut using ultra-microtome SEO (Sumy Electron Optics) model UMTP-6M at thickness $90 \mathrm{~nm}$, mounted on copper grids (200 mesh). Sections were stained with double stain (Uranyl acetate 5\% for $15 \mathrm{~min}$ followed by Lead citrate for $8 \mathrm{~min}$ and examined by Transmission Electron Microscope (Jeol Ltd, Tokyo, Japan) in Electron Microscope Research Unit, Faculty of Agriculture, Mansoura University, Egypt ${ }^{[21]}$.

\section{Biochemical study}

\section{Hormonal Analysis:}

At the time of sacrifice, blood samples from each rat were collected from orbital vein transferred to centrifuge tubes without anticoagulant, and serum was separated by low-speed centrifugation. The serum samples were stored at $-20^{\circ} \mathrm{C}$ until the analysis time. Serum thyroid hormones [T3, T4 and thyroid stimulating hormone (TSH)] levels were measured by in vitro diagnostic radioimmunoassay with the immunolite 2000 analyzer for the quantitative measurement) ${ }^{[22]}$.

\section{Oxidative stress markers}

Blood plasma was analyzed with high-performance liquid chromatography (HPLC) to determine malondialdehyde (MDA), superoxide dismutase (SOD) and catalase (CAT). Total plasma MDA was determined by HPLC according to the method of ${ }^{[23]}$

\section{Histo-morphometric analysis}

The image analyzer computer system Leica Qwin 500 (Leica Ltd, Cambridge, UK) at the Image Analyzing Unit of Pathology Department, Faculty of Dentistry, Cairo University, Egypt, was used to evaluate the area percent of GFAP, P53and calretinin proteins. The area percent was measured using the interactive measure menu. The measuring frame of a standard area equal to 118476.6 $\mathrm{mm} 2$ was chosen so that the brown positive immune reaction could be seen and masked by blue binary colour to be measured. Ten readings from five non-overlapping sections from each rat of all groups were examined.

\section{Statistical analysis}

All data are expressed as mean \pm SD and statistically analyzed. All analyses were carried out using the Statistical Package for the Social Sciences (SPSS) software, version 13.00 (Chicago, Illinois, USA). Statistical significance was determined by one-way analysis of variance for comparison between the means of the all groups. All data were analyzed using Student's $t$-test for comparison of the means, taking $P<0.05$ or $p<0.001$ as significant or highly significant level respectively.

\section{RESULTS}

\section{Histological study}

Light microscopic examination of the control subgroups showed no detectable differences so, subgroup la was considered as the control group.

HandE-stained sections of the control group revealed the C-shaped hippocampus was composed of the Cornu Ammonis (CA) in the form of CA1, CA2, CA3, CA4 and dentate gyrus (Fig. 1A). CA1 region of the control group showed three layers; polymorphic, pyramidal, and molecular. The pyramidal cells appeared with large vesicular nuclei. Blood capillaries were noticed in the molecular and polymorphic layers (Fig. 1B). Examination of HandE-stained sections of group II revealed pyramidal cells with lost nuclear details and vacuolations in the molecular and polymorphic layers. Numerous blood capillaries were also detected (Fig. 1C). In other sections in the same group, marked decrease in the cellular distribution in the three layers. Pyramidal cells showed small dark stained nuclei (Fig. 1D).

HandE stained sections in the CA1 region of the hippocampus of group III showed pyramidal nerve cells with large vesicular nuclei. Few cells with abnormal shaped nuclei were also detected (Fig. 1E). In group IV, three layers of CA1 region; polymorphic, pyramidal, 
and molecular were detected. Pyramidal cells had large vesicular nuclei. Blood capillaries were noticed in the molecular and polymorphic layers (Fig. 1F).

Examination of cresyl fast violet stained sections in CA1 region of the hippocampus of the control group showed purple Nissl granules in the perikarya of Pyramidal cells that appeared as around their nuclei (Fig. 2A). Sections in the CA1 region of Group II showed illdefined purple Nissl granules in the perikarya of Pyramidal cells (Fig. 2B). Sections of CA1region of the hippocampus of Groups III, and IV stained with Cresyl fast violet showed purple Nissl granules in the perikarya of Pyramidal cells (Figs. 2C, 2D).

\section{Immunohistochemical results}

Immunohistochemical reaction for GFAP in sections of CA1 area of the hippocampus of the control group revealed strong positive cytoplasmic reaction in the body and processes of astrocytes in the different layers of the hippocampus (Fig. 3A), that markedly decreased in group II as compared to the control group (Fig. 3B). Immunohistochemical results for GFAP-stained sections of group III revealed strong positive cytoplasmic reaction in most astrocytes (Fig. 3C). GFAP-stained sections for group IV revealed a strong positive expression of GFAP in astrocytes (Fig. 3D)

Immunohistochemical reaction for P53 in sections of CA1 area in the hippocampus of the control group revealed faint positive nuclear reaction of pyramidal cells (Fig. 4A). Strong positive nuclear reaction for P53 immunoreaction was detected in group II pyramidal cells as compared to the control group (Fig. 4B). Immunohistochemical results for P53 stained sections of group III revealed weak positive nuclear reaction in most pyramidal cells (Fig. 4C). P53 immunoreaction in sections of group IV revealed faint nuclear expression of pyramidal cells (Fig. 4D).

Immunohistochemical reaction for calretinin in sections of CA1 area in the hippocampus of the control group revealed strong positive reaction in the cytoplasm and processes of neuronal cells (Fig. 5A). Faint positive reaction for calretinin immunoreaction was detected in group II neuronal cells as compared to the control group (Fig. 5B). Immunohistochemical results for calretinin stained sections of group III revealed moderate positive reaction in most neuronal cells (Fig. 5C). Calretinin immunoreaction in sections of group IV revealed strong positive expression in neuronal cells (Fig. 5D).

\section{Transmission electron microscope results}

Electron microscopic examination of ultrathin sections in CA1 region of control hippocampus showed neuronal cells with vesicular nuclei (Fig. 6A). Group II ultrathin sections revealed marked degeneration of neurons that have small heterochromatic nuclei and vacuolated cytoplasm or cytoplasmic reminants (Fig. 6B). Group III ultrathin sections showed neurons that have euchromatic nuclei and others had vacuolated cytoplasm (Fig. 6C). Group IV ultrathin sections showed neurons that have euchromatic nuclei and oligodendrocyte had heterochromatic nuclei and electron dense cytoplasm (Fig. 6D).

\section{Histomorphometric and statistical results}

Statistically significant decrease in the mean area percent of GFAP immunoreaction was noticed in Group II as compared to Group I, Group III and Group IV. No statistically significant difference was seen in Group I as compared to Groups III and IV (Table 1 and Bar chart 1).

Highly statistically significant increase in the mean area percent of P53 immunoreaction was noticed in Group II as compared to Group I, Group III, and Group IV. No statistically significant difference was detected between Group I as compared to Groups III, and IV (Table 2 and Bar chart 2).

Statistically significant decrease in the mean area percent of calretinin immunoreaction was noticed in Group II as compared to Group I, Group III and Group IV. No statistically significant difference was seen in Group I as compared to Groups III and IV (Table 3 and Bar chart 2).

\section{Biochemical Results}

\section{Serum T3, T4 levels in the different studied groups}

Statistical analysis of the mean serum levels of T3 and $\mathrm{T} 4$ revealed a statistically significant decrease in the serum levels of group II as compared to the control, thyroid-supplemented and combined DON+thyroxin groups. On the other hand, there was a non-statistically significant difference between the control, thyroidsupplemented and combined $\mathrm{DON}+$ thyroxin groups (Table 4 and Bar chart 3).

\section{Serum TSH levels in the different studied groups:}

Statistical analysis of the mean serum level of TSH revealed a highly statistically significant increase ( $P$ value $<0.001)$ in group II as compared to the control, thyroid-supplemented and combined DON+thyroxin groups. On the other hand, there was no statistically significant difference between the control, thyroidsupplemented and combined $\mathrm{DON}+$ thyroxin groups (Table 4 and Bar chart 3).

\section{Anti-oxidative parameters results}

Highly statistically significant decrease $(P<0.05)$ in the levels of the superoxide dismutase (SOD), catalase (CAT), and malondialdehyde (MDA) enzymes was noticed in CA1region of hippocampus tissue of group II when compared to the control, thyroid-supplemented and combined DON+thyroxin values. No statistically significant difference was observed between control, thyroid-supplemented and combined DON+thyroxin groups (Table 5 and Bar chart 4). 
Table (1): The mean area percent of GFAP immunoreaction in different studied groups

\begin{tabular}{lccc}
\hline & Mean \pm SD & F & Pvalue \\
\hline GI & $38.1 \pm 5.43$ & & \\
GII & $11.02 \pm 1.13$ & & \\
GIII & $34.52 \pm 1.54$ & 101.02 & $<0.01^{*}$ \\
GIV & $37.2 \pm 6.11$ & & \\
\hline
\end{tabular}

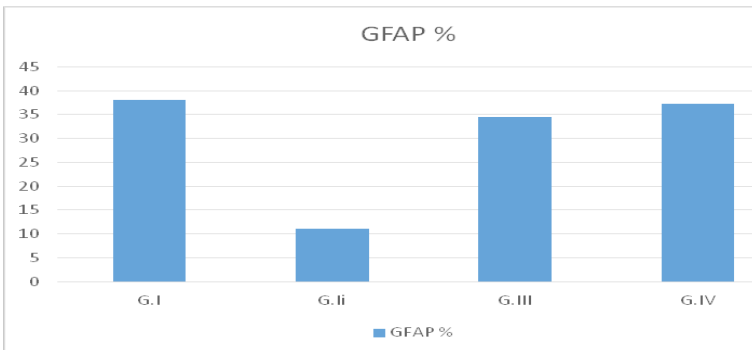

Bar chart 1: GFAP \% in different groups

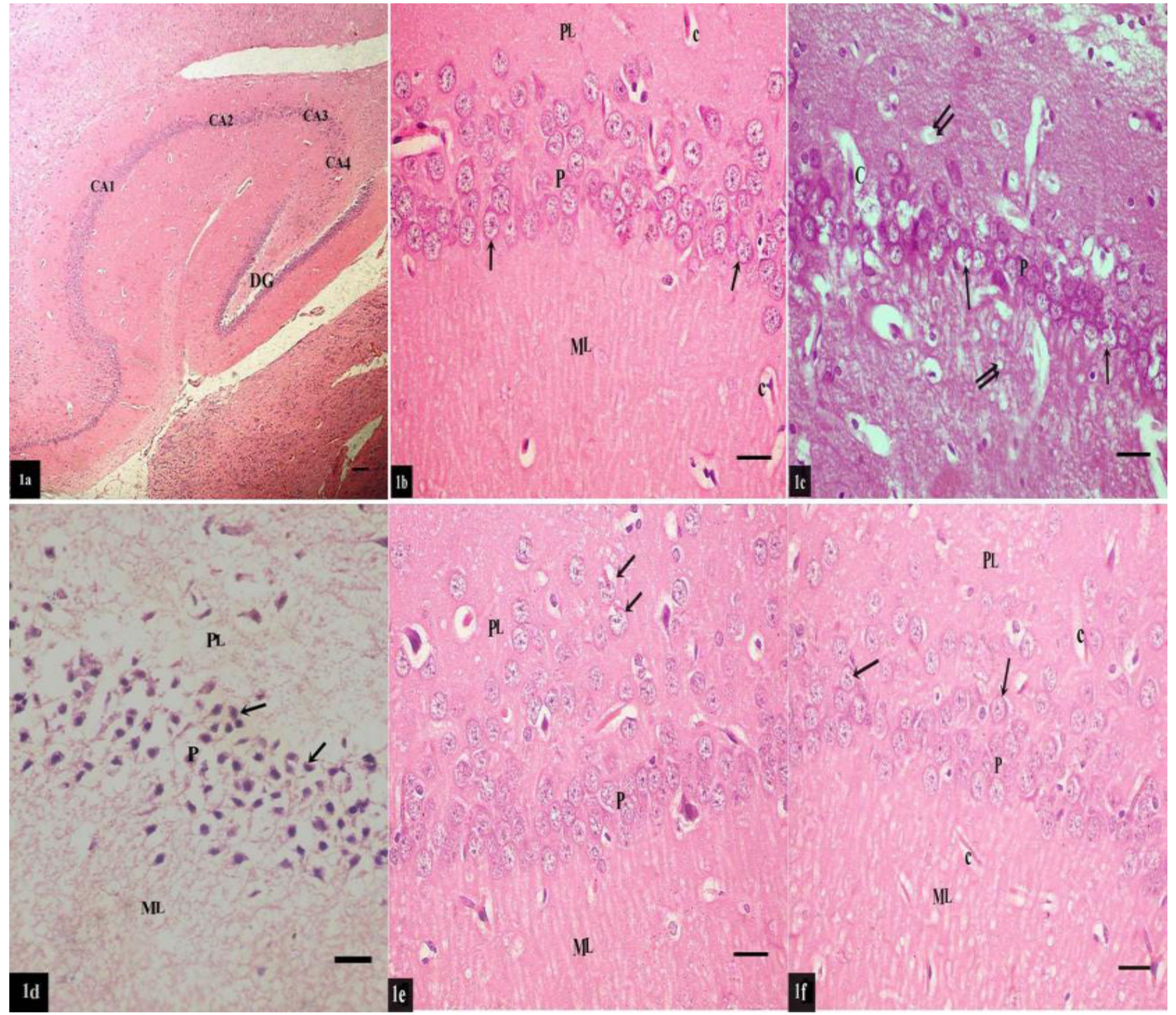

Fig. 1: A photomicrograph of a HandE stained section 1a: in the hippocampus of control group shows C-shaped hippocampus consists of the Cornu Ammonis (CA) in the form of CA1, CA2, CA3, CA4 and dentate gyrus.(HandE, $\times 40$, scale bar $100 \mu \mathrm{m}), 1 \mathrm{~b}$ : in the CA1 region of the control hippocampus shows the three layers; polymorphic (PL), pyramidal (P), and molecular (ML). The pyramidal cells appear with large vesicular nuclei (arrow). Blood capillaries (c) are noticed in the molecular and polymorphic layers. (HandE, $\times 400$, scale bar $20 \mu \mathrm{m}), 1 \mathrm{c}$ : in CA1 of group II hippocampus shows pyramidal cells $(\mathrm{P})$ with lost nuclear details (arrow) and vaculations (double arrow) in the molecular and polymorphic layers. Numerous blood capillaries (C) are also seen (HandE, $\times 400$, scale bar $20 \mu \mathrm{m}), 1 \mathrm{~d}$ : In other section of group II showing marked decrease in the cellular distribution in the three layers; polymorphic (PL), pyramidal (P), and molecular (ML). Pyramidal cells show small dark stained nuclei (arrow)(HandE, $\times 400$, scale bar $20 \mu \mathrm{m})$, 1e: in CA1 region of the hippocampus group III showing polymorphic (PL), pyramidal (P), and molecular (ML) layers. Pyramidal cells (P) with large vesicular nuclei. Few cells with abnormal shaped nuclei (arrow) are also detected. (HandE, $\times 400$, scale bar $20 \mu \mathrm{m}$ ), 1f: in CA1 region of the hippocampus of group IV shows three layers of CA1 region; polymorphic (PL), pyramidal (P), and molecular (ML) layers. Pyramidal cells have large vesicular nuclei (arrow). Blood capillaries (c) are noticed in the molecular and polymorphic layers. (HandE, $\times 400$, scale bar $20 \mu \mathrm{m}$ ) 

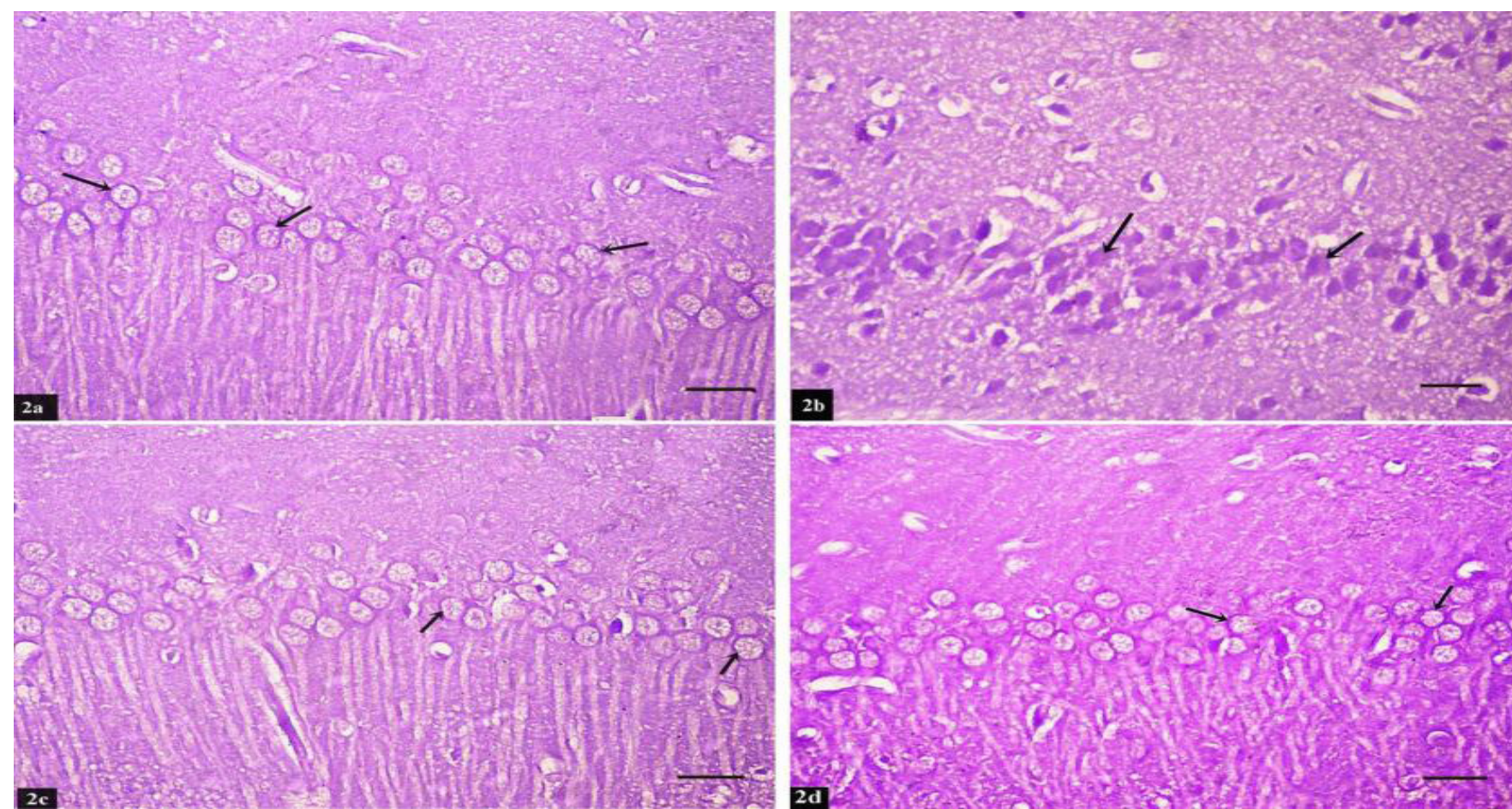

Fig. 2: A photomicrograph of cresyl fast violet stained sections in CA1 region of the hippocampus 2a: of the control group shows purple Nissl granules (arrow) in the perikarya of Pyramidal cells that appear around their nuclei. 2b: of group II shows ill-defined purple Nissl granules (arrow) in the perikarya of Pyramidal cells. 2c: of group III shows purple Nissl granules (arrow) in the perikarya of Pyramidal cells. 2d: of group IV shows purple Nissl granules (arrow) in the perikarya of Pyramidal cells (Cresyl fast violet x 400, scale bar $20 \mu \mathrm{m}$ )

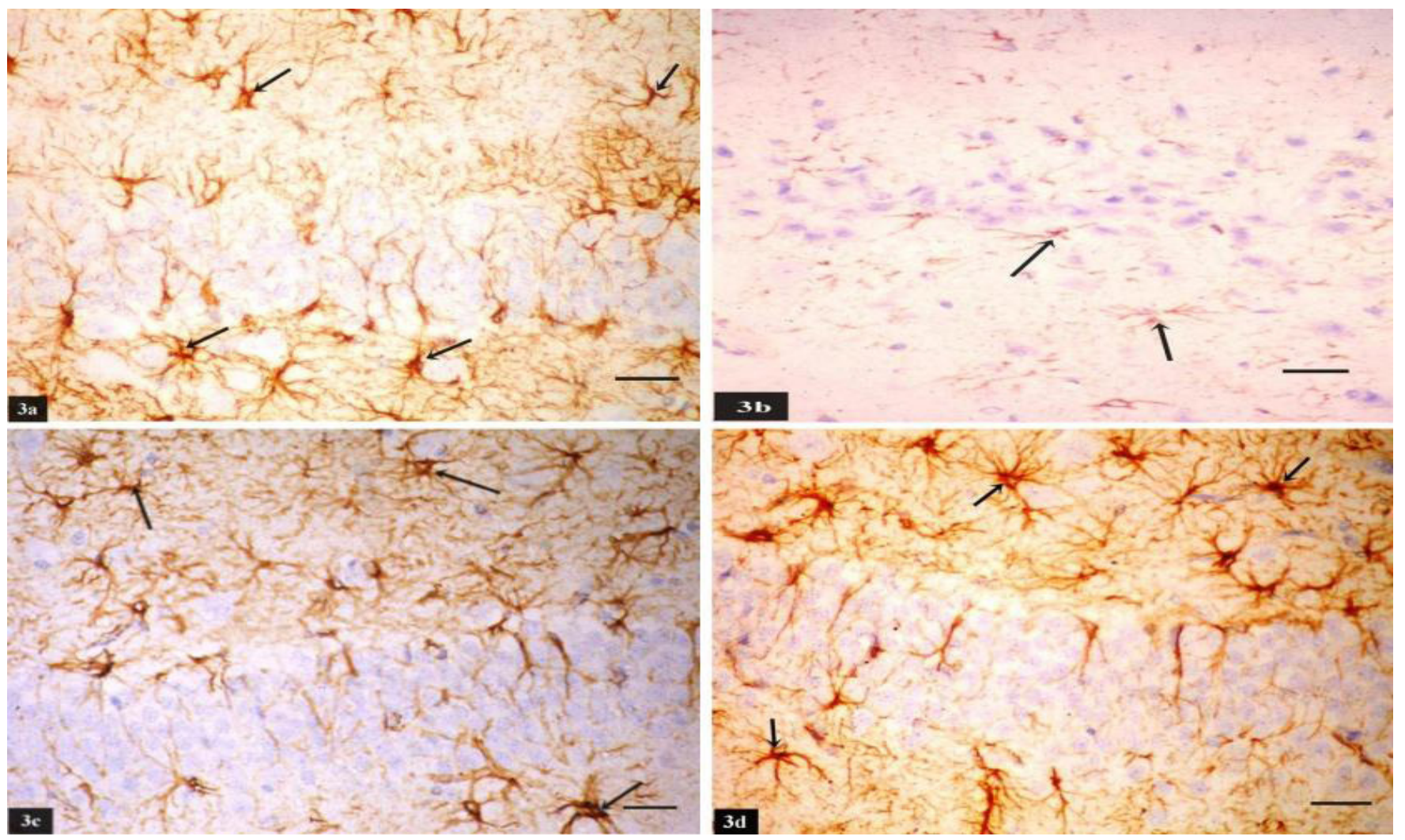

Fig. 3: GFAP immunostaining of a section 3a: in CA1 area of the control hippocampus reveals strong positive cytoplasmic reaction in the body and processes of astrocytes (arrow) in the different layers of the hippocampus. 3b: in CA1 area of group II hippocampus reveals marked decrease in the cytoplasmic reaction (arrow) of astrocytes in the body and processes as compared to the control group. 3c: in CA1 area of group III hippocampus reveals strong positive cytoplasmic reaction in most astrocytes (arrow). 3d: in CA1 of group IV hippocampus reveals a strong positive expression of GFAP (arrow) in astrocytes. (Immunoperoxidase technique for GFAP x 400, scale bar $20 \mu \mathrm{m}$ ) 


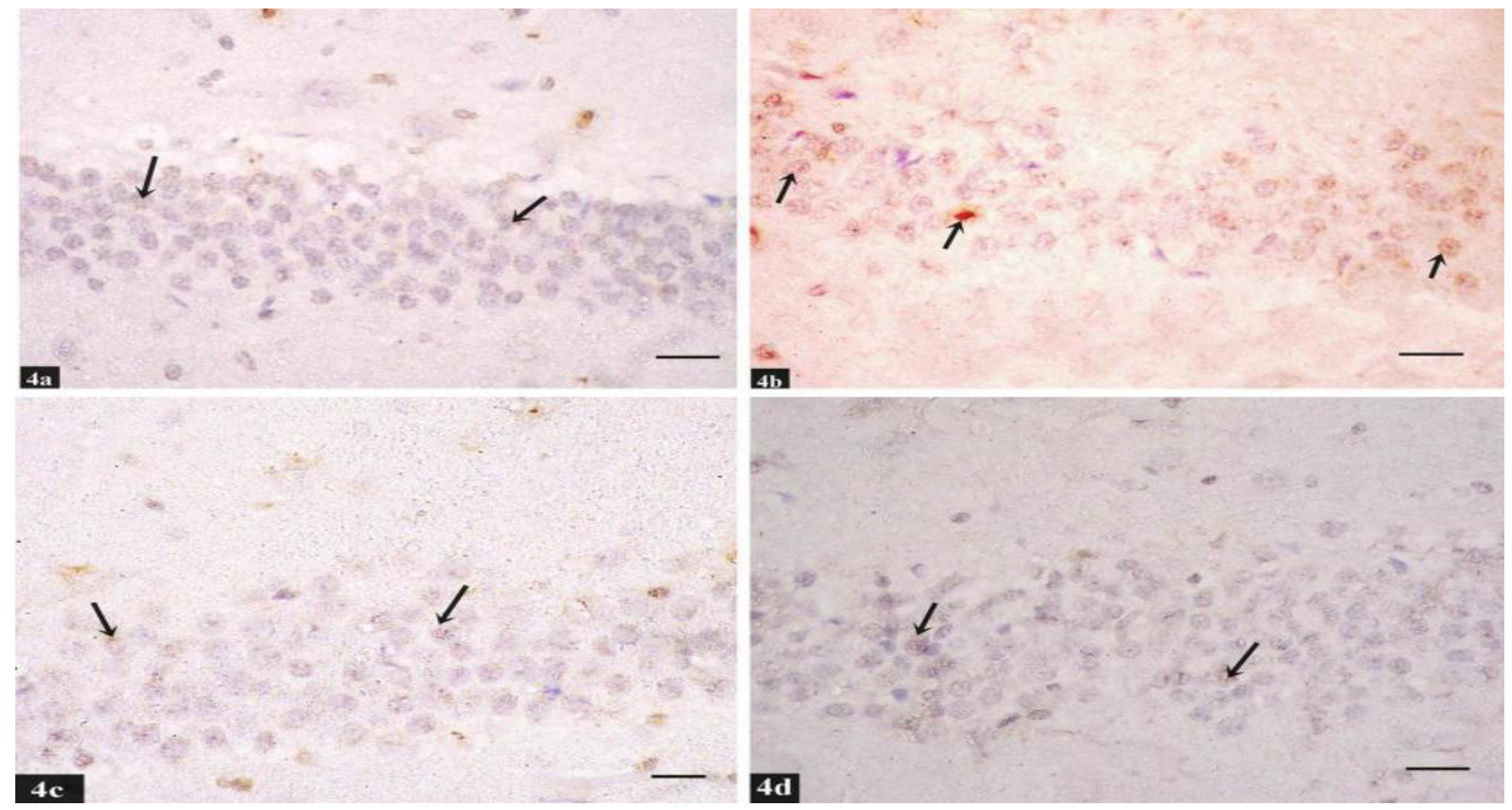

Fig.4: Immunohistochemical staining for P53 4a: in a section of CA1 area in the control hippocampus reveals faint positive nuclear reaction of pyramidal cells (arrow).4b: Strong positive nuclear reaction for P53 immunoreaction is detected in group II pyramidal cells (arrow) as compared to the control group. 4c: in a section of group III reveals weak positive nuclear reaction in most pyramidal cells (arrow).

4d: in a section of group IV reveals faint nuclear expression of pyramidal cells (arrow). (Immunoperoxidase technique for P53 x 400, scale bar $20 \mu \mathrm{m}$ )
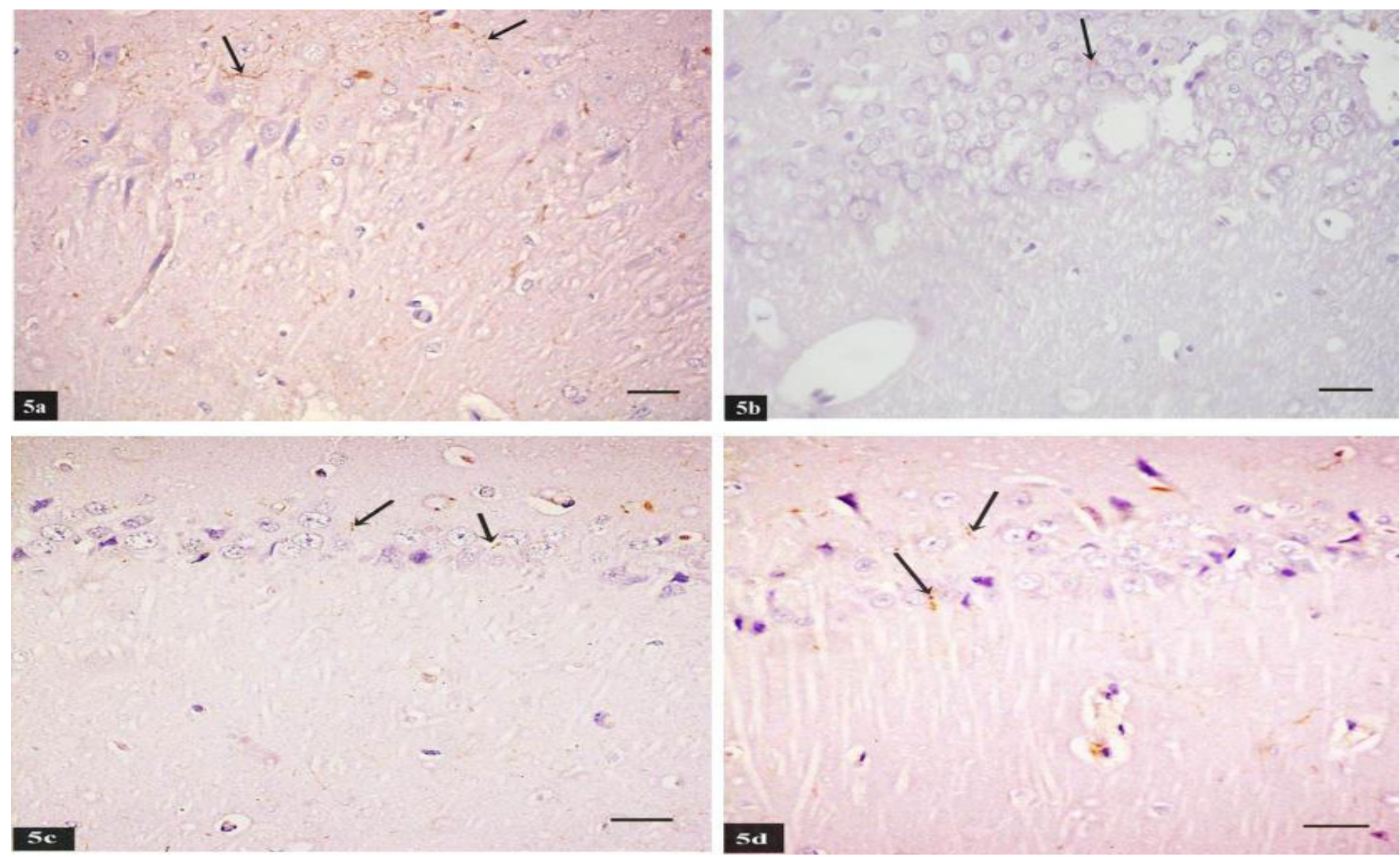

Fig.5: Immunohistochemical reaction for calritinin 5a: in a section of CA1 area in control hippocampus reveals strong positive reaction in the cytoplasm and processes of neuronal cells (arrow).5b: in a section of group II showed faint positive immunoreaction for calretinin neuronal cells (arrow) as compared to the control group. $5 \mathrm{c}$ : in a section of group III reveals moderate positive reaction in most neuronal cells (arrow). $5 \mathrm{~d}$ : in a sections group IV reveals strong positive expression in neuronal cells (arrow). (Immunoperoxidase technique for calritinin x 400, scale bar $20 \mu \mathrm{m}$ ) 

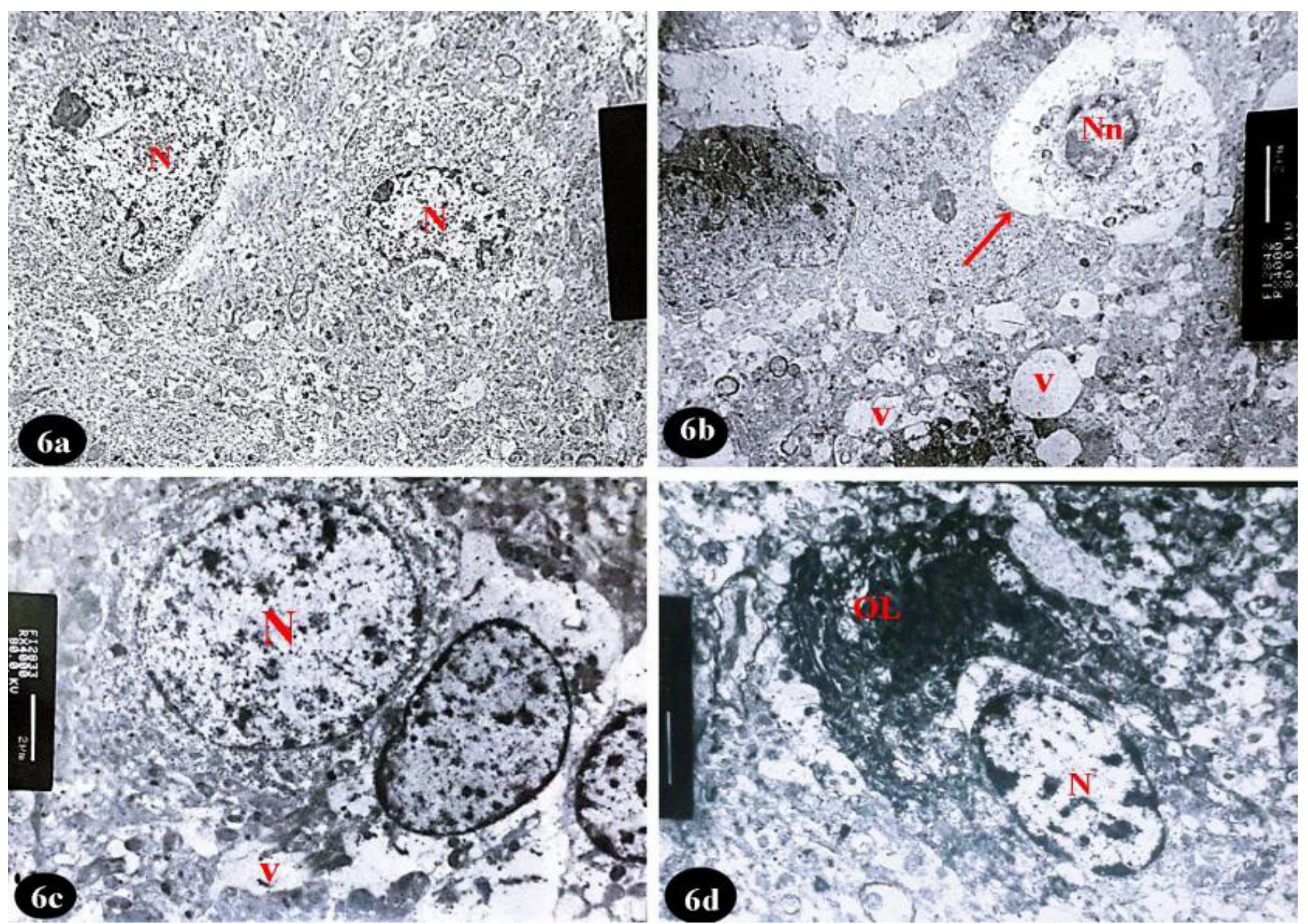

Fig.6: 6a Electron microscopic examination of ultrathin sections in CA1 region of control hippocampus shows neuronal cells with vesicular nuclei (N). 6b: reveals marked degeneration of neurons with small heterochromatic nucleus $(\mathrm{Nn})$ and vacuolated cytoplasm (arrow) or cytoplasmic reminants(V). 6c: shows one neuron has euchromatic nucleus $(\mathrm{N})$ and other one with vacuolated cytoplasm $(\mathrm{V})$. 6d: reveals neuron with euchromatic nucleus $(\mathrm{N})$ and oligodendrocyte $(\mathrm{OL})$ with heterochromatic nucleus and electron dense cytoplasm.

Table (2): The mean area percent of P53 immunoreaction in different studied groups

\begin{tabular}{lccc}
\hline & Mean \pm SD & F & P value \\
\hline GI & $1.5 \pm 0.9$ & & \\
GII & $20.8 \pm 5.3$ & & \\
GIII & $2.1 \pm 0.4$ & 23.46 & $<0.001^{* *}$ \\
GIV & $1.3 \pm 0.8$ & & \\
\hline
\end{tabular}

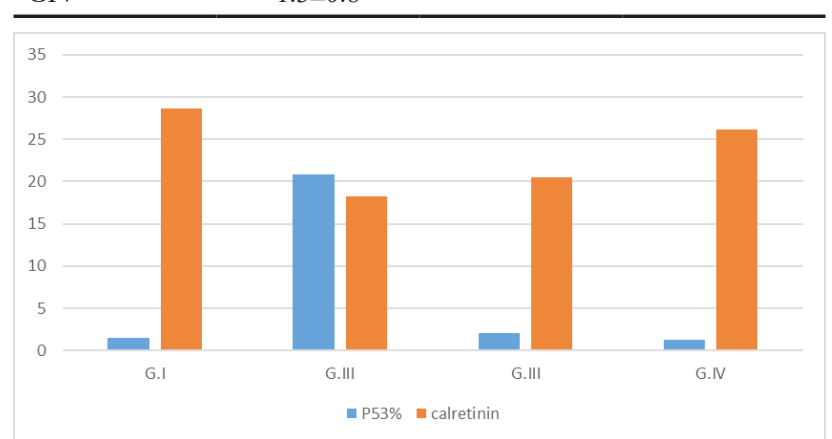

Bar chart 2: P53 and calretinin \% in different groups
Table (3): The mean area percent of calritinin immunoreaction in different studied groups

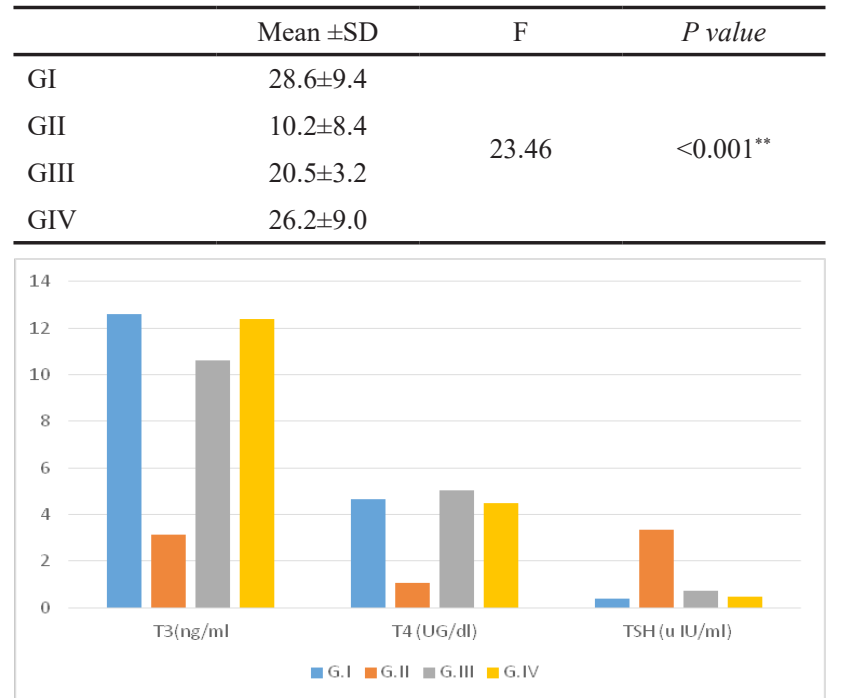

Bar chart 3: T3, T4 and TSH serum level in different groups 
Table (4): The mean $($ Mean $\pm \mathrm{SD})$ serum T3, T4 and TSH in different studied groups:

\begin{tabular}{lcccc}
\hline \multicolumn{1}{c}{ Items } & Group I & Group II & Group III & Group IV \\
\hline T3 (ng/ml) & $12.58 \pm 3.05$ & $3.14 \pm 1.63$ & $10.62 \pm 2.08$ & $12.41 \pm 2.04$ \\
T4 (UG/dl) & $4.66 \pm 1.41$ & $1.06 \pm 0.22$ & $5.04 \pm 2.06$ & $4.47 \pm 4.09$ \\
TSH $(\mathrm{u} \mathrm{IU} / \mathrm{ml})$ & $0.36 \pm 0.22$ & $3.32 \pm 0.40$ & $0.74 \pm 1.01$ & $0.48 \pm 0.26$ \\
\hline
\end{tabular}

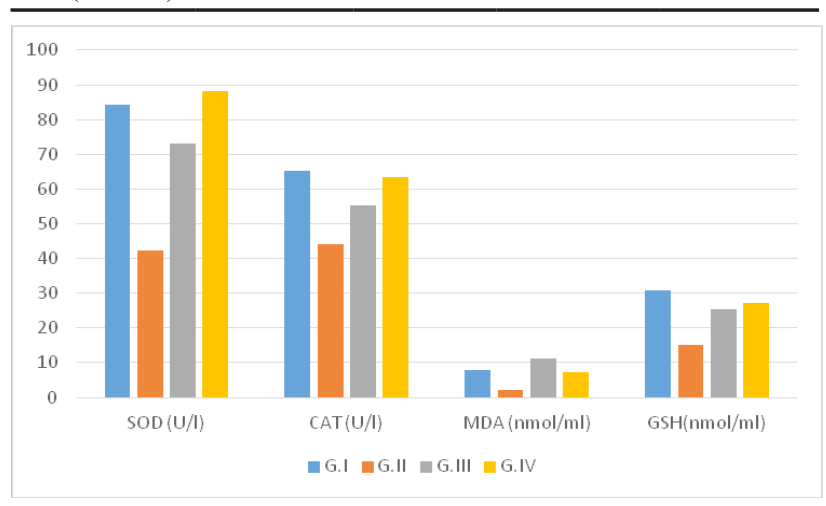

Bar chart 4: SOD, CAT and MDA level in different groups

Table 5: The mean values of SOD, CAT and MDA levels among different studied groups

\begin{tabular}{lcccc}
\hline \multicolumn{1}{c}{ Items } & Group I & Group II & Group III & Group IV \\
\hline SOD (U/l) & $84.19 \pm 2.47$ & $42.37 \pm 6.25$ & $73.05 \pm 2.55$ & $88.32 \pm 2.36$ \\
CAT (U/1) & $65.11 \pm 2.08$ & $44.08 \pm 2.11$ & $55.23 \pm 2.12$ & $63.41 \pm 3.12$ \\
MDA $(\mathrm{nmol} / \mathrm{ml})$ & $7.91 \pm 0.03$ & $2.22 \pm 0.34$ & $11.29 \pm 0.13$ & $7.23 \pm 0.21$ \\
GSH $(\mathrm{nmol} / \mathrm{ml})$ & $30.96 \pm 6.02$ & $14.97 \pm 1.65$ & $25.43 \pm 5.86$ & $27.23 \pm 5.76 \mathrm{gr}$ \\
\hline
\end{tabular}

\section{DISCUSSION}

The brain is an important target for thyroid hormones ${ }^{[24]}$. During perinatal period, the expression of thyroid hormone receptors in the rat brain increases rapidly and the consequences of hypothyroidism are more dramatic resulting in numerous alterations ${ }^{[25]}$. The hippocampus is a precious sensitive area that involved in many emotional and motivational functions. Several studies reported the vulnerability of hippocampal different areas to developmentally induced hypothyroidism ${ }^{[26]}$.

Examination of HandE stained sections in hippocampal CA1 region of thyroidectomized rats revealed pyramidal cells with lost nuclear details and vacuolations in the molecular and polymorphic layers. Numerous blood capillaries were also detected. The hippocampus is a highly sensitive neural structure to the actions of THs due to its high content of thyroid receptors. The persistence of these receptors in adulthood would indicate a role of thyroid hormones in the mature brain. Adult-onset hypothyroidism results in mood and behaviour abnormalities like anxiety, and depression-like symptoms, as well as memory impairment ${ }^{[27]}$ as well as decreases the number of newborn neuroblasts and impairs the adult neurogenesis particularly in the hippocampus ${ }^{[28]}$.

The same group showed marked decrease in the cellular distribution in the three layers. Pyramidal cells showed small dark stained and heterochromatic nuclei and ill-defined purple Nissl granules. Marked degeneration of neurons with vacuolated cytoplasm or cytoplasmic reminants were seen in this group. THs are important in the establishment of the CA1 gradient of pyramidal cell differentiation and in the development of the relationship between pyramidal and granule cells in the hippocampus. It was reported that THs deficiency leads to distortions resulted from reduction in the number and maturation of both granule and pyramidal cells. Such distortions may be cause functional and maturation impairments of those cells. So, the structural organization of pyramidal cell in CA1 region and its characteristic palisade arrangement was absent with a significantly reduced volume of the CA1 pyramidal cell layers ${ }^{[29]}$. Other author explained that by cell death andl or disturbance of neurogenesis due to THs lack $^{[30-31]}$.

Early studies investigating the effects of hypothyroidism on the CA1 region of the hippocampus of adult brain demonstrated a reduction in the volume, weight, and numerical density of cells within the CA1 regions of the hippocampus ${ }^{[32-33]}$. They suggested that THs have an influence on the survival of adult hippocampal progenitors and subsequent neurogenesis and differentiation through THs receptors relevant role. Ambrogini et al.$^{[34]}$ hypothizes that thyroid hormones promote cell survival by preventing apoptosis.

In this regard, the cells in hippocampus of group II (thryoidectomized rats) showed strong positive immunoreaction for P53 protein. Apoptosis is important for normal brain development as $20-50 \%$ of neurons are known to undergo Programmed cell death (PCD). PCD leads to an apoptotic morphology involves the interplay of many pro- and anti-apoptotic genes and their activity appears to control cell death. THs is known to regulate nuclear genes by binding to its nuclear receptor and modulate cell cycle ${ }^{[35]}$. The lack of THs affects the expression of apoptotic genes and modulate cell death during neurogenesis. Some researchers observed that THs deficiency leads to enhanced DNA fragmentation and negatively influences the survival of newborn cells, in particular immature neurons, and newborn cells show a delay in their neuronal differentiation ${ }^{[36]}$.

In the CNS, astrocytes are the main protectors of neurons and are involved in neuron migration and maturation, myelination, ionic regulation, metabolism of neurotransmitters and synaptic integration ${ }^{[37]}$. Glial fibrillary acidic protein (GFAP) belongs to the group of intermediate filaments of the cell cytoskeleton. It is present in astrocytes and its detection is useful for the identification of astrocytes in a highly specific manner.In the present work, it was found that GFAP immunostained cells were reduced in thyroidectomized rats (group II).It has been revealed that hypothyroidism is associated with impaired myelination, delayed development of the dendritic tree, reduced glial cells and axo-dendritic synapses ${ }^{[38]}$ as well as Remaud et al..$^{[39]}$ showed that short-term adult-onset hypothyroidism significantly impairs dendrite arborization 
of immature neurons in the sub-granular zone of the dentate gyrus.

In vitro, THs have been reported to modulate astrocyte morphology, differentiation, and proliferation and to regulate extracellular matrix (ECM) organization and synthesis. In vivo, THs regulate radial astrocyte transition and the vimentin-GFAP switch, a hallmark of astrocyte differentiation, in the basal forebrain and hippocampus ${ }^{[40]}$. Interestingly, hypothyroidism altered the phosphorylating system associated with cytoskeleton of both neuron and astrocyte but supplementation with $\mathrm{T} 3$ did not reverse either neuronal and astrocyte IF hyperphosphorylation ${ }^{[41]}$.

Loss of GABAergic CR interneurons plays an important role in axonal sprouting of inhibitory GABAergic interneurons, especially a transient increase of CR-IR neurons within hippocampus. Spine-free calretininimmunoreactive (CR-IR) interneurons found significantly decreased in this work. A characteristic feature of these cells located in all areas and layers is the frequent dendrodendritic and axo-dendritic contacts. Anatomical and physiological studies revealed a wide spectrum of different inhibitory interneurons with considerable differences, both in physiological parameters and in the dendritic, as well as axonal arborization pattern in hypothyroidism ${ }^{[42]}$.

TEM analysis revealed marked degeneration of neurons that have small heterochromatic nuclei and vacuolated cytoplasm or cytoplasmic reminants. In adult-onset hypothyroidism, the expression of SNAP25 is upregulated in hippocampus with mild cognitive impairment. Also, destructive changes in nerve cells and disorders of mitochondria functions are associated with increased oxidative stress that led to marked ultrastructural changes in the neurons with reductions in of pyramidal cells number. The neurons displayed a scanty cytoplasm with few organelles ${ }^{[37,43]}$. Thyroxin replacement result in attenuating the alterations induced by hypothyroidism, some neurons had euchromatic nuclei and others had vacuolated cytoplasm ${ }^{[44]}$. However, group IV showed neurons that have euchromatic nuclei and oligodendrocyte had heterochromatic nuclei and electron dense cytoplasm. It is well established that the cholinergic system is involved in higher brain functions such as learning and memory. It is well established that the cholinergic system is involved in higher brain functions such as learning and memory. Some authors' results demonstrated that T4 and DON administered in combination resulted in more effective restoration levels of $\mathrm{ACh}$ and synaptic proteins than either alone $\mathrm{e}^{[14,19,45,46]}$

Oxidative stress is an imbalance between the production of oxidizing agents and antioxidant activity of defence systems. Mitochondria are the core cell organelle that uses oxygen to produce energy. However, $1-2 \%$ of the oxygen used by the mitochondria is incomplete and leads to the production of superoxide radicals in cells that are deactivated immediately. These superoxide radicals together with the non-radical oxygen and hydrogen peroxide species are known as reactive oxygen species (ROS), which attack different biomolecules such as proteins, DNA and lipids and mediate the process known as oxidative stress ${ }^{[47]}$.

This present study recorded a state of imbalance in redox system in experimental group (II) where MDA increased with decreased CAT and SOD. It has been shown that THs dysregulation affects antioxidant/oxidant balance and promote ROS generation ${ }^{[48]}$. Goharbari et al. ${ }^{[49]}$ observed that deficiency of THs induces higher levels of hydrogen peroxide (H2O2) in mitochondria and a decrease in catalase activity with a rise of total SOD and glutathione peroxidase activities.Also, It has also been described that hypothyroidism modulates the composition of fatty acids of the cellular membrane by increasing the levels of polyunsaturated and reducing the levels of monosaturated fatty acids ${ }^{[50]}$.

Thyroid-replacement group showed pyramidal nerve cells with large vesicular nuclei. Few cells with abnormal shaped nuclei were also detected. Also, there was a strong positive GFAP cytoplasmic immunoreaction in most astrocytes with weak P53 immunoreaction in pyramidal cells. These finding indicated some improvement in morphology and molecular structur of cells in CA1. Thyroid hormones (T4andT3), act on most tissues, including the kidneys, the heart and the adipose tissue, and exert important actions during development and maturation ${ }^{[51]}$. The rat brain was considered as the best animal model of thyroid hormone dependent brain development ${ }^{[52]}$, especially the hippocampus as being a highly sensitive neural structure to the actions of thyroid hormones due to its high content of thyroid receptors as described by MartiCarbonell ${ }^{[53]}$. It is not only during development but also in adulthood ${ }^{[24]}$. Adult-onset hypothyroidism is linked to impaired learning and memory, as well as to depression ${ }^{[46]}$. It was reported that such condition could be improved with TH supplementation. Both THs (T4 and T3) may enter the CNS through specific transporters; T4 is converted to the active TH (T3) in glial cells, astrocytes, and tanycytes, although the main target cells are found in neurons and maturing oligodendrocytes ${ }^{[29]}$. Within the CNS, THs influence a large number of effects such as neural-cell migration, growth, differentiation and signalling ${ }^{[2]}$. The nuclear $\mathrm{TH}$ receptor belongs to the steroid/TH receptor superfamily of ligand-dependent transcription factors. So, THs positively regulate a large number of genes ${ }^{[54]}$. THs promote CNS repair through CNS re-myelination and non-genomic and genomic effects on mitochondrial biogenesis and function. So, decreased activity of THs in humans is linked to impaired mitochondrial biogenesis and function $^{[47-48]}$.

In group III, the hippocampus return to normal morphological structure and nearly biochemical results approach to control level. This group supplemented with combined therapy of TH and DON. Another study reported that following the $\mathrm{T} 4+\mathrm{DON}$ treatment, the morphological alterations, including the neurons, the synapses and 
the myelin sheath were similar to that of the control group $^{[55]}$. The reversible changes of the acetyl cholin (Ach) concentration and acetyl cholinesterase (AChE) activity by T4 supplementation were also observed in other brain regions, such as the hippocampus of the adult hypothyroid rats ${ }^{[56]}$. The results above indicated that $\mathrm{ACh}$ and AChE may be under direct thyroid hormone control. It is well established that the cholinergic system is involved in higher brain functions such as learning and memory. The authors demonstrated that experimentally-induced hypothyroidism decreased $\mathrm{ACh}$ content, as well as $\mathrm{AChE}$ activity in hippocampus and spinal cord of the adult rats ${ }^{[57]}$. Other researches documented that DON treatment resulted in amelioration of impairments induced by hypothyroidism as it compensates for ACh depletion in the brain. ${ }^{[58]}$.

Both clinical and experimental reports have described impairment of cognition, learning and memory in adult hypothyroid humans and animals. Adult hypothyroidism also induces a depression-like disorder, as well as slowing of thoughts and movements ${ }^{[59]}$.

Besides, adult-onset hypothyroidism could induce these changes by its affection on CA1 region of rat hippocampus. The most relevant finding of this work is that THs needed for the proper acquisition of new granular neurons at adult stages. Also, showed that adult-onset hypothyroidism impaired hippocampal proliferative capacity and suggest a relationship with a depressive-like behaviuor. The fact that THs replacement reverses the cellular and biochemical changes. Moreover, we concluded that THs replacement must concurrently with donepezil for complete recovery from all symptoms associated with adult-onset hypothyroidism.

\section{CONFLICTS OF INTEREST}

There is no conflict of interest to declare.

\section{REFERENCES}

1. Ghassabian A, Bongers-Schokking J,Henrichs J, Jaddoe VW, Visser TJ, Visser W, Keizer-Schrama SM, Hooijkaas H, Steegers EA, Hofman A, Verhulst FC, Ende V, Rijke YB, Tiemeier H. Maternal thyroid function during pregnancy and behavioral problems in the offsprings: The generation R study. Pediatric Research. 2011;69: 454-459

2. Horn S, Heuer H. Thyroid hormone action during brain development: more questions than answers. Mol. Cell Endocrinol. 2010; 315(1-2),19-26.

3. Samuels MH. Cognitive Function in Subclinical Hypothyroidism. J Clin Endocrinol Metab.2010; 95(8):3611-3613

4. Hage MP, Azar ST. The link between thyroid function and depression. Journal of Thyroid Research. Volume 2012; 590648, 1-8 (review article)

5. Correia N, Mullally S, Cooke G, Tun TK, Phelan
N, Feeney J, Fitzgibbon M, Boran G, O’Mara S, Gibney J. Evidence for a Specific Defect in Hippocampal Memory in Overt and Subclinical Hypothyroidism. J Clin Endocrinol Metab, 2009; 94(10):3789-3797

6. Lynette A, Desouza A, Ladiwal U, Daniel SM, Agashe S, Vaidya RA, Vaidyaa VA. Thyroid hormone regulates hippocampal neurogenesis in the adult rat brain. Mol. Cell. Neurosci.2005; 29: $414-426$

7. McHugh SB, Campbell TG, Taylor AM, Rawlins JN, Bannerman DM. A Role for Dorsal and Ventral Hippocampus in Inter-Temporal Choice Cost-Benefit Decision Making. Behavioral Neuroscience. 2008; 122(1): 1-8

8. Kempermann G, Song H, Gage FH. Neurogenesis in the Adult Hippocampus.Cold Spring Harb Perspect Biol. $2015 ; 1 ; 7(9): 1-15$

9. Samuels BA and Hen R. Neurogenesis and affective disorders. European Journal of Neuroscience. 2011; 33:1152-1159

10. Osama MA, El-Gareib AW, El-Bakry AM, Abd Eltawab SM, Ahmed RG. Thyroid hormones states and brain development interactions. Review, Int. J. Devl. Neuroscience. 2008; 26: 147-209 .

11. Rovet JF. The Role of Thyroid Hormones for Brain Development and Cognitive Function Paediatric Thyroidology. 2014; 26:26-43

12. Pepeu G ,Giovannini MG. Cholinesterase inhibitors and beyond. Curr Alzheimer Res.2009; 6: 8696.

13. Yoshiyama Y, Kojima A, Ishikawa C, Arai K. Anti inflammatory action of donepezil ameliorates tau pathology, synaptic loss and neurodegeneration in a tauopathy mouse model. J Alzheimers Dis.2010; 22: 295306.

14. Schwaller B. Calretinin: from a "simple" $\mathrm{Ca} 2+$ buffer to a multifunctional protein implicated in many biological processes. Frontiers in Neuroanatomy..2014;8(3):1-7 mini review articl

15. Seib DRM, Martin-Villalba A. Neurogenesis in the Normal Ageing Hippocampus: A Mini-ReviewGerontology.2015; 61:327-335.

16. Abuhamed M, Bo X, Kun X, Fang Y, Long L. Voltage-gated channels as causative agents for epilepsies. Am J Immunol. 2008;4: 43-50.

17. Tóth K, Maglóczky Z. The vulnerability of calretinin-containing hippocampal interneurons to temporal lobe epilepsy. Frontiers in Neuroanatomy.2014;8:1-12(review article)

18. Kosasa T, Kuriya Y, Yamanishi Y. Effect of 
donepezil hydrochloride (E2020) on extracellular acetylcholine concentration in the cerebral cortex of rats. Jpn. J. Pharmacol.1999; 81, 216-222.

19. Oncu M, kanter M, Gokcimen A, kavakli D, Oncu M, Ural M, karaoz E. Effect of thyroidectomy on the histology of rat sublingual gland. APMIS.2004 ;112: 119-22.

20. Ramos-Vara JA, Kiupe M, Baszler T, Bliven L, Brodersen B, Chelack B, Czub S, Del Piero F, Dial S, Ehrhart EJ, Graham T, Manning L, Paulsen D, Valli VE, West K. Suggested guidelines for immunohistochemical techniques in veterinary diagnostic laboratories. J Vet Diagn Invest.2008; 20:393-413.

21. Goodhew P, Humphreys J, Beanland R. Electron Microscopy and Analysis, 3rd edn. (2001). Taylor and Francis, London.

22. El-Wakf AM, Hassan HA, El-said FG, El-Said A. Hypothyroidism in male rats of different ages exposed to nitrate polluted drinking water. Research Journal of Medicine and Medical Science.2009; 4(2): 160-164.

23. Helal OK, Mousaa AM, Kandee N. Effect of antox on hippocampal structure in male albino rats exposed to lead toxicity: histological and biochemical study. The Egyptian Journal of Histology.2011; 34: 808-817.

24. Williams GR. Neurodevelopmental and neurophysiological actions of thyroid hormone. J. Neuroendocrinol.2008; 20: 784-794.

25. Schroeder AC and Privalsky ML. Thyroid hormones,T3 andT4, in the brain. Frontiers in Endocrinology. 2014; 5 | Article 40 :1-6 mini review article

26. Dong H, Yauk CL, Rowan-Carro A, You S, Thomas Zoeller R, Lambert I, Wade MG. Identification of Thyroid Hormone Receptor Binding Sites and Target Genes Using ChIP-on-Chip in Developing Mouse Cerebellum. PLoS ONE 2009;4(2):1-12

27. Montero-Pedrazuela A , 'ndez-Lamo IF, Alieva M, Pereda-Perez I, Venero C, Guadano-Ferraz A. Adult-Onset Hypothyroidism Enhances Fear Memory and Upregulates Mineralocorticoid and Glucocorticoid Receptors in the Amygdala. Plos One.2011;6(1):1-10

28. Cooke GE, Mullally S, Correia N, O’Mara SM, Gibney J. Hippocampal volume is decreased in adults with hypothyroidism. Thyroid.2014;24(3):433-40.

29. Harte-Hargrove LC, Varga-Wesson A,. Duffy AM, Milner TA, Scharfman HE. Opioid ReceptorDependent Sex Differences in Synaptic Plasticity in the Hippocampal Mossy Fiber Pathway of the
Adult Rat. The Journal of Neuroscience. 2015; 35(4):1723-1738 - 1723

30. Koromilas C, Liapi C, Schulpis KH, Kalafatakis $\mathrm{K}$, Zarros A, Tsakiris S. Structural and functional alterations in the hippocampus due to hypothyroidism. Metab Brain Dis.2010; 25: 339-354.

31. Corte's C, Eugenin E, Aliaga E, Carreno LJ, Bueno SM, Gonzalez PA, Gayol S, Naranjo D, Noches V, Marassi MP, Rosenthal D, Jadue C, Ibarra P, Keitel C, Wohllk N, Court F, Kalergis AM, Riedel CA. Hypothyroidism in the Adult Rat Causes Incremental Changes in BrainDerived Neurotrophic Factor, Neuronal and Astrocyte Apoptosis, Gliosis, and Deterioration of Postsynaptic Density. Thyroid.2012; 22( 9): 951-963.

32. Kapoor R, van Hogerlinden M, Wallis K, Ghosh $\mathrm{H}$, Nordstrom K,Vennstrom B, Vaidya VA. Unliganded thyroid hormone receptor alpha1 impairs adult hippocam $\neg$ pal neurogenesis. FASEB J.2010; 24: 4793-4805.

33. Kapoor R, Ghosh H, Nordstrom K, Vennstrom B, Vaidya VA. Loss of thyroid hormone receptor beta is associ $\neg$ ated with increased progenitor proliferation and NeuroD positive cell number in the adult hippocampus. Neurosci Lett.2011; 487 : 199-203.

34. Ambrogini P, Cuppini R, Ferri P, Mancini C, Ciaroni S, Voci A, Gerdoni E, Gallo G. Thyroid hormones affect neurogenesis in the dentate gyrus of adult rat. Neuroendocrinology.2005; 81: 244-253.

35. Franklin JL. Redox Regulation of the Intrinsic Pathway in Neuronal Apoptosis. Antioxidants and Redox Signaling.2011; 14(8):1-12

36. Martí-Carbonell MA, Garau A, Sala-Roca J, Balada F. Effects of adult dysthyroidism on the morphology of hippocampal granular cells in rats. Acta Neurobiol Exp.2012; 72: 230-239

37. Cheng C, Sourial M, and Doering LC. Astrocytes and Developmental Plasticity in Fragile X. Neural Plasticity Volume 2012, Article ID 197491, 12 pages

38. Harsan L, Steibel J, Zaremba A, Agin A, Sapin R, Poulet P, Guignard B, Parizel N, Grucker D, Boehm N, Miller RH, Ghandour MS. Recovery from Chronic Demyelination by Thyroid Hormone Therapy: Myelinogenesis Induction and Assessment by Diffusion Tensor Magnetic Resonance Imaging. The Journal of Neuroscience, 2008; 28(52):14189 -14201

39. Remaud S, Gothié JD, Morvan-Dubois G, 
Demeneix BA. Thyroid hormone signaling and adult neurogenesis in mammals. Fronteirs in Endocrinology. 2014 | Volume 5 | Article 62:1-7

40. Dezonne RS, Stipursky J, Gomes FCA. Effect of thyroid hormone depletion on cultured murine cerebral cortex astrocytes. Neuroscience Letters.2009; 58-62.

41. Zamoner A, Heimfarth L, Pessoa-Pureur R. Congenital hypothyroidism is associated with intermediate filament misregulation, GLAST glutamate transporters down-regulation and MAPK activation in developing rat brain. Neurotoxicology.2008; 29: 1092-1099.

42. Cauli B, Zhou X, Tricoire L, Toussay X, Staiger JF. Revisiting enigmatic cortical calretinin-expressing interneurons. Frontiers in Neuroanatomy.2014; 8(Article 52): 1-18

43. Cao L, Jiang W, Wang F, Yang QG, Wang C, Chen YP, Chen GH. The reduced serum free triiodothyronine and increased dorsal hippocampal SNAP-25 and Munc18-1 had existed in middleaged CD-1 mice with mild spatial cognitive impairment. Brain Res.2013; 1540: 9-20

44. RosiNczuk J, Dymarek R, CaBkosiNski I.Histopathological, Ultrastructural, and Immunohistochemical Assessment of Hippocampus Structures of Rats Exposed to TCDD and High Doses of Tocopherol and Acetylsalicylic Acid.BioMed Research International. Volume 2015:1-13

45. Wang N, Cai Y, Wang F, Zeng X, Jia X, Tao F, Zhu D. Effects of thyroxin and donepezil on hippocampal acetylcholine content and syntaxin-1 and munc-18 expression in adult rats with hypothyroidism. Exp Ther Med.2014; 7: 529-536

46. Wang F, Zeng X, Zhu Y, Ning D, Liu J, Liu C, Jia X ,Zhu D. Effects of thyroxine and donepezil on hippocampal acetylcho $\neg$ line content, acetylcholinesterase activity, synaptotagmin 1 and SNAP 25 expression in hypothyroid adult rats. Mol Med Rep.2015; 11: 775782

47. Amini E, Rezaei M, Mohamed Ibrahim N, Golpich M, Ghasemi R, Mohamed Z, et al. A Molecular approach to epilepsy management: from current therapeutic methods to preconditioning efforts. Mol Neurobiol.2015;52(1):492-513

48. Wilms L, Larsen J, Pedersen PL, Kvetny J. Evidence of mitochondrial dysfunction in obese adolescents. Acta Paediatr.2010;99(6):906-11.

49. Goharbari MH, Shadboorestan A, Abdollahi
M. Inhibitory effects of thyroid hormones on mitochondrial oxidative stress: A systematic review.International journal of pharmacology.2016;12(3):249-261.

50. Sahoo D, Roy A, Bhanja S, Chainy G. Hypothyroidism impairs antioxidant defence system and testicular physiology during development and maturation. General and Comparative Endocrinology.2008; 156(1): 63-70

51. Lass P, Slawek J, Derejko M, Rubello D. Neurological and psychiatric disorders in thyroid dysfunctions. The role of nuclear medicine: SPECT and PET imaging. Minerva Endocrinol.2008; $33: 75-84$

52. Moreno M, de Lange P, Lombardi A, Silvestri E, Lanni A, Goglia F. Metabolic effects of thyroid hormone derivatives. Thyroid.2008; 18:239-253.

53. Hou YY, Lu B, Li M, et al. Involvement of actin rearrangements within the amygdala and the dorsal hippocampus in aversive memories of drug withdrawal in acute morphine-dependent rats. J Neurosci.2009;29(39):12244-12254.

54. Maggio M, Dall'Aglio E, Lauretani F, et al. The hormonal pathway to cognitive impairment in older men. J Nutr Health Aging.2012;16(1):40-54.

55. Huang YH, Tsai MM, Lin KH. Thyroid hormone dependent regulation of target genes and their physiological significance. Chang Gung Med J .2008;31:325-334

56. wang F, wu Z, Zha X, Cai Y, Wu B, Jia X, Zhu D. Concurrent administration of thyroxine and donepezil induces plastic changes in the prefrontal cortex of adult hypothyroid rats. Molecular Medicine Reports.2017; 16: 3233-3241

57. Westerholz S, De Lima A, Voigt T. Regulation of early spontaneous network activity and GABAergic neurons development by thyroid hormone. Neuroscience.2010;168(2):573-89.

58. Yang H, Zha X, Cai Y, Wang F, Wu Z, Wu B, Jia $\mathrm{X}$, Zhu D. Impacts of thyroxine combined with donepezil on hippocampal ultrastructures and expressions of synaptotagmin-1 and SNAP-25 in adult rats with hypothyroidism. Int J Clin Exp Med.2015;8(10):17922-17931

59. Gerges NZ, Al-Zoubi KH, Park CR, Diamond DM, Alkadhi KA. Adverse effect of the combination of hypothyroidism and chronic psychosocial stress on hippocampus-dependent memory in rats. Behavioural Brain Research.2014; 155:77-84. 
الملخص العربى

الدونزبيل يحسن التغيرات النسيجية والكيميائية الحيوية للحصين في قصور الغدة الدرقية لذكور

\author{
داليا عبد المعين محمد وسماح محمد أحمد \\ قسم الأنسجة وبيولوجيا الخلية ـ كلية الطب ـ جامعة الزقازيث
}

المقدمة: تتسبب الاختلالات الهرمونية في العديد من الأمر اض ، مثل الاضطر ابات العصبية والنفسية. يبلغ معدل حدوث قصور

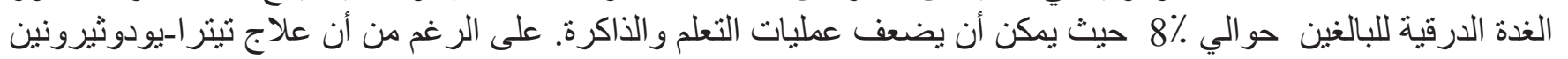

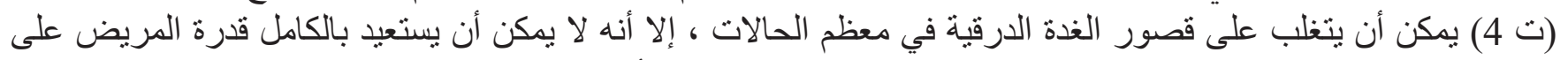

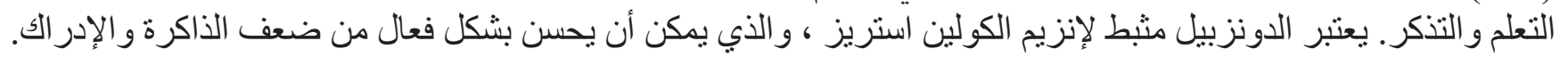

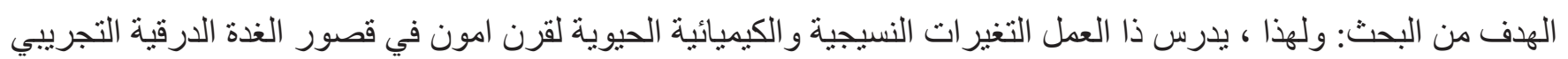

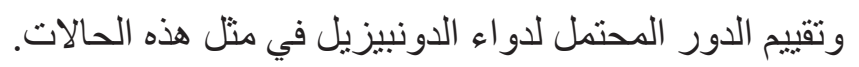

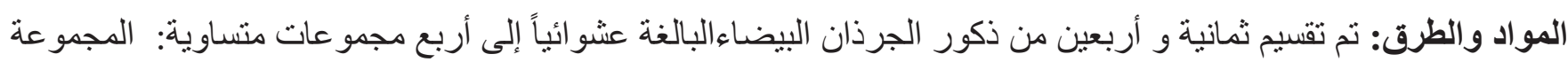

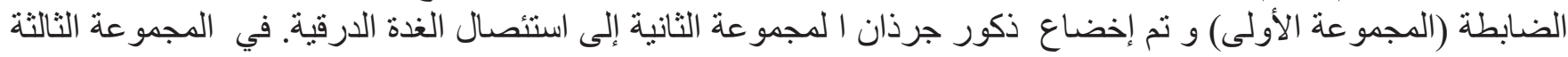

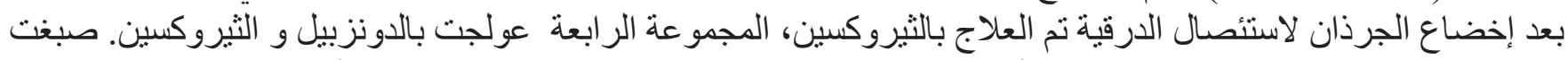

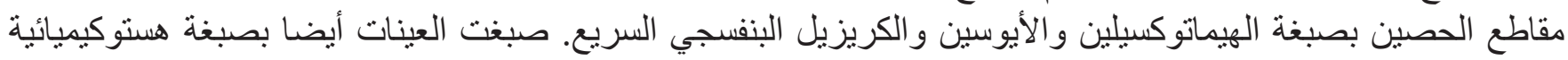
مناعية لبروتين ل P53 و GFAP calritinin و كما استخدم الميكروسكوب الالكتروني و تم تسجيل النتائج وتحليلها إحصائيا.

النتائج: و أظهرت نتائج المجمو عة الثانية زيادة موت الخلايا الخلايا العصبية و الخلايا النجمية مع بالمقارنة مع الضوابط. الخبا علاوة على ذلك , زيادة تفاعل GFAP في الخلايا النجمية ، ازدادت الثن عو امل التأكسد.

الخلاصة: نستخلص من هذه الدر اسة أن العلاج بالثيروكسين أدى إلى بعض التحسن في التغير ات النسيجيه و البيوكيميائية للغدة

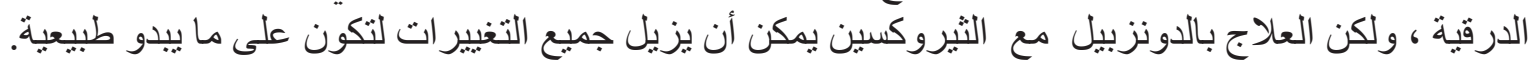

